\title{
Influence of Masonry Infill on Seismic Design Factors of Reinforced-Concrete Buildings
}

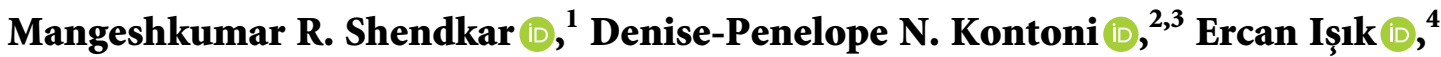 \\ Sasankasekhar Mandal, ${ }^{1}$ Pabitra Ranjan Maiti, ${ }^{1}$ and Ehsan Harirchian ${ }^{5}{ }^{5}$ \\ ${ }^{1}$ Department of Civil Engineering, Indian Institute of Technology (IIT-BHU), Varanasi 221 005, India \\ ${ }^{2}$ Department of Civil Engineering, School of Engineering, University of the Peloponnese, 26334 Patras, Greece \\ ${ }^{3}$ School of Science and Technology, Hellenic Open University, 26335 Patras, Greece \\ ${ }^{4}$ Department of Civil Engineering, Bitlis Eren University, 13100 Bitlis, Turkey \\ ${ }^{5}$ Institute of Structural Mechanics (ISM), Bauhaus-Universität Weimar, 99423 Weimar, Germany \\ Correspondence should be addressed to Denise-Penelope N. Kontoni; kontoni@uop.gr
}

Received 15 October 2021; Revised 14 December 2021; Accepted 25 January 2022; Published 27 February 2022

Academic Editor: Zeqi Lu

Copyright (c) 2022 Mangeshkumar R. Shendkar et al. This is an open access article distributed under the Creative Commons Attribution License, which permits unrestricted use, distribution, and reproduction in any medium, provided the original work is properly cited.

\begin{abstract}
Infill walls are the most common separator panels in typical reinforced-concrete (RC) frame structures. It is crucial to investigate the influence of the infill walls on the earthquake behavior of RC frames. The load resistance of infill materials was often not taken into account in the designing phase, whereas the infill walls have significant contributions to the structural behavior under lateral and vertical loadings. A three-dimensional 4-story RC building is designed, and in order to make a realistic model, different infill walls configurations were taken into account with the openings in the infill. Four different models were created for structural analysis for infill wall effects, namely, full RC infilled frame (Model I), corner infill at ground story RC infilled frame (Model II), open ground story RC infilled frame (Model III), and bare RC frame (Model IV). Static adaptive pushover analysis has been performed for all structural models by using the SeismoStruct software. The double strut nonlinear cyclic model was used for modeling the infill walls. In this study, three different compressive strengths of infill walls are taken into consideration, and the effects on seismic design factors (namely, the response reduction factor, the ductility, the overstrength factor, and the deflection factor) are calculated. The obtained values of the response reduction factor $(R)$ are compared with the given values in the BIS code. The results show that the $R$ factors of all RC infilled frames are decreased when the compressive strength of the masonry infill reduces. However, the $R$ values of bare frames are less than the corresponding values recommended in the BIS code. It is worth noting that the National Earthquake Hazards Reduction Program (NEHRP) provisions underestimate the deflection factors of the reinforced-concrete (RC) frames according to the evaluated deflection factors of the herein studied RC frames.
\end{abstract}

\section{Introduction}

In developing countries, the model of multilevel reinforcedconcrete (RC) frames with infill walls is the most popular type used in housing and business constructions $[1,2]$. In general, only the weight of the infill wall materials is taken into consideration, and the other strength parameters are ignored. The structural behavior of such frames considerably depends on the dynamic characteristics, including stiffness, bearing capacity, period, and damping level of the related infill walls loaded laterally and vertically [3-6]. Out-of-plane and in-plane infill walls damage are commonly seen after destructive earthquakes $[7,8]$. Therefore, the response of RC structures with masonry infill walls under the impact of earthquakes is worth calculating [9-11]. The infill wall damage in RC structures after the earthquake also reveals the importance of this issue [12-14]. Therefore, the "frameinfill" interaction in earthquake-prone areas is one of the most important parameters in RC structures. In this context, a great deal of research work has been done on the infill in 
RC frames as a result of improvement in computational and experimental methods [15-18]. In these studies, the effects of different parameters on infill were examined. The response reduction coefficient is one of these parameters.

The earthquake behavior of a 5-story RC existing building in the city of Madinah due to the different infill configurations in the frames was presented by Alguhane et al. [19]. In that study, structural analyses were performed using four different infill wall models according to ASCE 4106 [20]. They evaluated the response modulation coefficient from the capacity design spectra for all structural models. The authors concluded that the response modification coefficient of the bare frame did not meet the Saudi Building Code (SBC 301) requirement. However, with the inclusion of infill in the frames, the response modification coefficient and the overstrength factor increased and met the code requirement [19]. The evaluation of the response reduction coefficient of a 5-story RC structure for different earthquake zones by considering the nonductile and ductile detailing design provisions was performed by Goud and Pradeepkumar [21]. These authors concluded that the $R$ value given by the Indian code is more conservative. The $R$ values for zone II and zone III are on the safe side, and zone IV and $\mathrm{V}$ are closer to the assumed value of $\mathrm{R}$. The member sizes also affect the $R$ factor values of structures [21]. A study on establishing the response reduction coefficient $(R)$ and displacement amplification factors $\left(C_{\mathrm{d}}\right)$ for buildings with seismic design codes was made by Uang [22]. That author derived the expression of response reduction factor and displacement amplification factor used in the provisions of the National Earthquake Hazards Reduction Program (NEHRP) [23]. Both these factors depend on the structural overstrength factor and ductility factor. In NEHRP provisions, the $C_{\mathrm{d}} / R$ ratio is also recommended, and it is totally dependent on the structural ductility factor only. The effect of damping is generally counted in the ductility reduction coefficient. It was concluded that the values of $R$ and $C_{\mathrm{d}}$ recommended by NEHRP are not consistent with various structural systems, and these values should be reevaluated in a more rational manner [22]. Shendkar and Pradeepkumar [24] presented the numerical simulation of RC frames with unreinforced masonry (URM) and semi-interlocked masonry (SIM). For this purpose, seven structural models by different infill configurations were used for numerical analyses. The pushover analysis was used for the calculation of the response reduction coefficient by using the SeismoStruct software. The $R$ values were lower in the RC-URM panel frame as compared to the RC-SIM panel frame because the SIM panels show behavior as energy dissipating equipment according to their geometrical shapes. Thus, the $R$ factor is also susceptible to the geometrical and material characteristics [24].

Generally, seismic design codes incorporate the nonlinearity present in the structure by the response reduction factor $(R)$. This $R$ factor decreases the elastic to the inelastic response. The $R$ factor, which differs according to the codes of different countries, has taken names such as "response reduction factor," "response modification coefficient," "behavior factor," and "response reduction coefficient." The
Bureau of Indian Standard (BIS) code does not give any specific explanation on different issues like the effect of infill wall consideration (with and without openings), structural and geometrical configuration, and irregularities. There is also a need to study the effect of the compressive strength of infill on the major seismic parameters of different structures.

In this research, the following objectives are undertaken:

(i) Finding the realistic response reduction factor and deflection factor of RC infilled frames for different infill configurations along with the opening in infill walls, by using the adaptive pushover analysis, and comparing them with the values recommended by the BIS code and NEHRP provisions.

(ii) Computing the influence of compressive strength of masonry infill on the actual response reduction factor and deflection factor of different RC frames.

(iii) Evaluating the performance point of the different structures and its correlation with the response reduction factor.

(iv) Identifying the actual damage pattern of different $\mathrm{RC}$ infilled frames based on the material strain limit approach.

\section{Methodology}

2.1. Adaptive Pushover Analysis. Pushover analysis is widely used to control the nonlinear response of structures $[25,26]$, and it is one of the effective analysis types for nonlinear dynamic analysis of buildings under earthquake impact. One of the limitations of such approaches in tall buildings is that the effect of high modes is ignored. Therefore, it is suggested by Kalkan and Kunnath [27] and Gupta and Kunnath [28] that higher mode effects should be taken into account by adaptive pushover procedures involving changes in dynamic characteristics like frequency and time period. The adaptive pushover analysis was used herein in all structural models. The adaptive pushover analysis, which is applied to the estimation of the horizontal capacity of any building, takes full account of the influence of the latter's deformation and input motion frequency content on the dynamic response characteristics. The participation factors and mode shapes obtained from the results of the eigenvalue analysis are taken into account at each step during the adaptive pushover analysis. The types of load control used in adaptive pushover analysis are similar to conventional pushover analysis [29-32]. The shape of the loading vector in this analysis is automatically defined and updated at each step of analysis [33]. In this study, for spectral amplification, the timehistory record of the Chi-Chi earthquake (place: Taiwan, date: 20 September 1999, source: PEER database [34]) was considered. The flowchart of the adaptive pushover analysis is shown in Figure $1[30,35]$ for this analysis type.

2.2. Response Reduction Factor $(R)$. The nonlinear response of a building under earthquake impact via a response reduction factor $(R)$ is included in many current seismic design codes [36, 37]. The response reduction factor is 


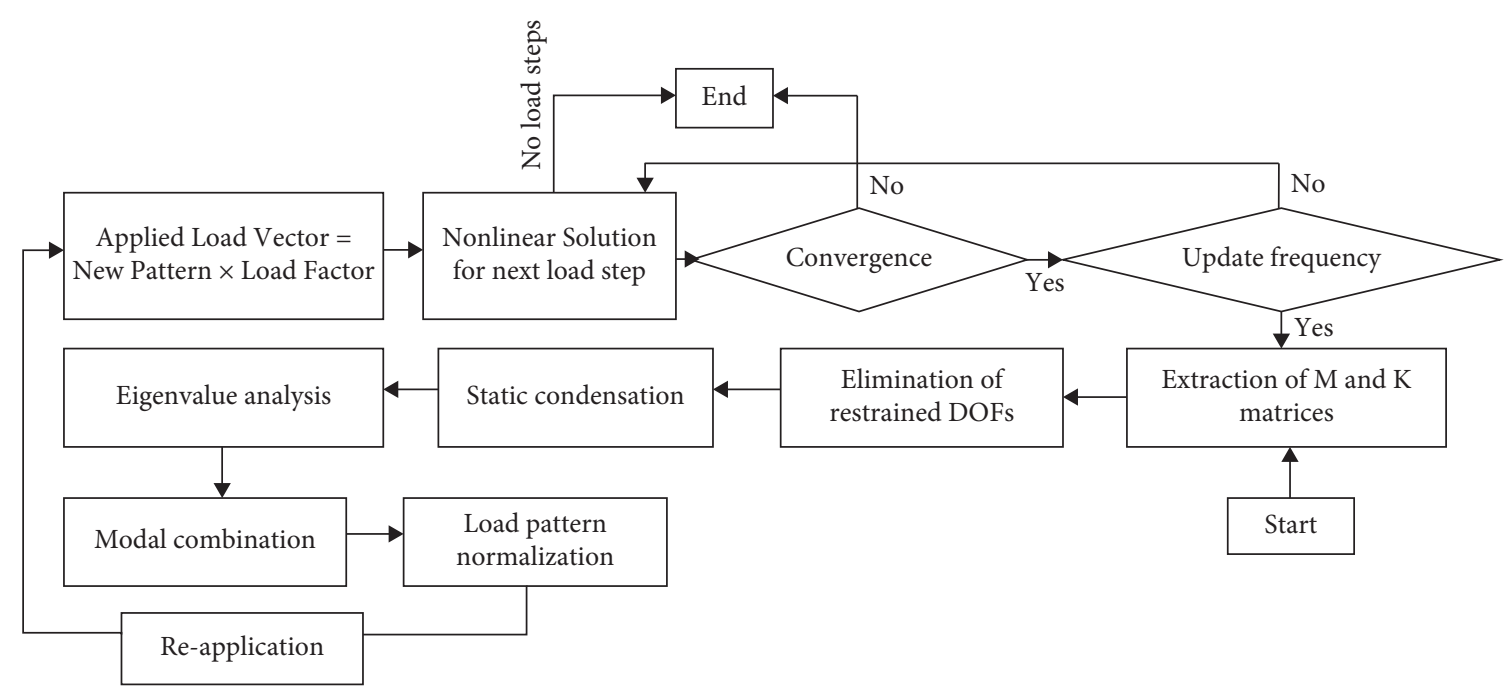

Figure 1: Flowchart of an adaptive pushover analysis.

defined as the ratio of elastic strength to inelastic design strength. Three main factors, such as overstrength, redundancy, and ductility factors, affect the $R$ factor (ATC 19) [38]. It can be defined as follows:

$$
R=R_{O} \times R_{R} \times R_{d}
$$

where $R_{\mathrm{d}}$ defines ductility reduction factor, $R_{\mathrm{O}}$ is the overstrength factor, and $R_{\mathrm{R}}$ is the redundancy factor.

Herein, the $R$ factor is identified as below according to BIS code (IS 1893 (Part 1): 2016 [39]):

$$
2 R=R_{d} \times R_{O}
$$

The relationship between these three factors is shown in Figure 2 [36].

The recommended values by the IS 1893 (Part 1): 2016 [39] for the response reduction factor are given in Table 1.

The ductility reduction factor is basically related to the fundamental period and ductility of any building. The displacement ductility $(\mu)$ is identified as the ratio of maximum displacement $\left(\Delta_{\max }\right)$ to the yield displacement $\left(\Delta_{y}\right)$. The maximum displacement corresponds to peak base shear, and the yield displacement is obtained via the reduced stiffness approach [40]. The ductility reduction factor is calculated based on the Newmark and Hall theory [41]. The overstrength factor measures the reserved strength present in a building. In this study, the redundancy factor is taken into consideration with the overstrength factor.

2.3. Deflection Amplification Factor $\left(C_{d}\right)$. The deflection amplification factor is used to calculate the maximum inelastic displacement according to NEHRP [23], as shown in Figure 3 [42].

The deflection amplification factor $C_{\mathrm{d}}$ can be expressed as by Uang [22] as follows:

$$
C_{d}=\mu \times R_{o}
$$

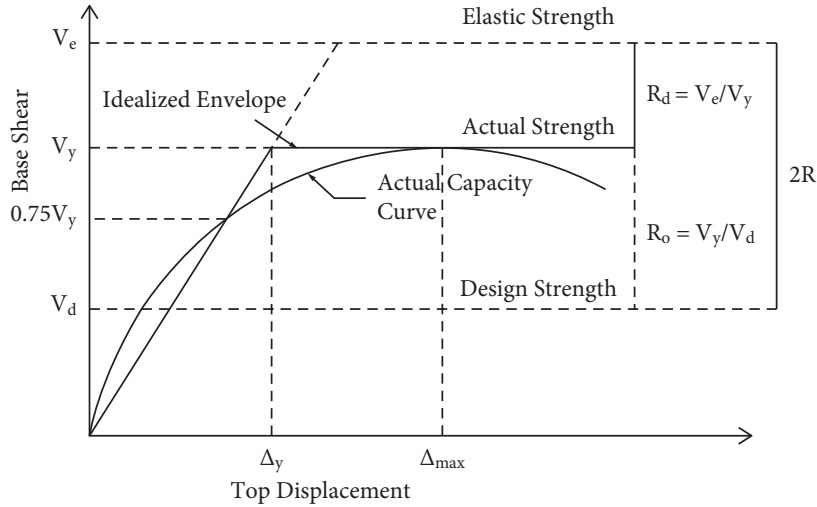

Figure 2: The relationship between $R, R_{d}$, and $R_{o}$ factors.

TABLE 1: Response reduction factor by IS1893 (Part 1): 2016 [39].

\begin{tabular}{ll}
\hline Frame system & $R$ \\
\hline OMRF (ordinary moment-resisting frame) & 3
\end{tabular}

SMRF (special moment-resisting frame)

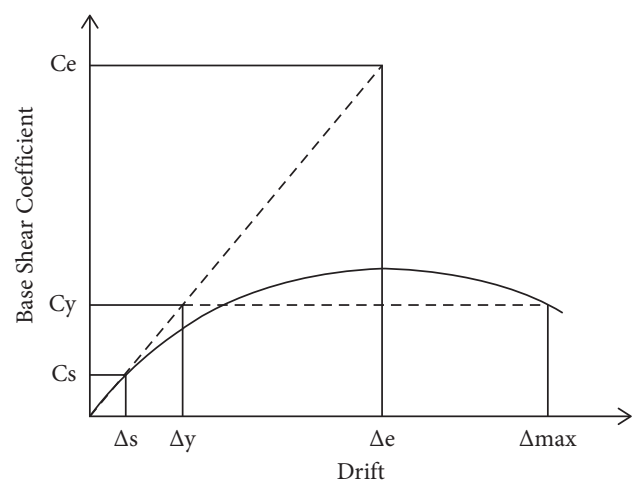

FIGURE 3: Inelastic behavior on seismic response.

In addition,

$$
\Delta_{\max }=\Delta_{s} \times C_{d},
$$


where $\Delta_{\max }$ is the maximum inelastic deflection and $\Delta_{\mathrm{s}}$ is the deflection computed from the elastic static analysis of structure. In seismic design, it is important to calculate the maximum inelastic displacement due to many reasons, including the following:

(a) Evaluating the minimum building separation distance to avoid pounding effect.

(b) Evaluating the maximum story drift.

(c) Checking the deformation capacity of the critical structural members.

The suggested values for deflection amplification factor in NEHRP [23] are given in Table 2. Note that, in this study, the calculated deflection factor is based on (2).

2.4. Performance Point. In this study, the performance point is calculated according to the displacement coefficient method. This approach employs a direct numerical operation to calculate the expected displacement of the structures under earthquake impact. It is an approach that does not need to transform the capacity curve into spectral coordinates. Performance point is also called target displacement. The target displacement for structural models is calculated according to ASCE 41-06 [20].

$$
\delta_{t}=C_{0} C_{1} C_{2} S_{a} \frac{T_{e}{ }^{2}}{4 \pi^{2}} g,
$$

where $\delta_{t}$ is the target displacement; $C_{0}$ is the modification factor calculated from displacements of the building such as the roof displacement and the spectral displacement of an equivalent (SDOF) system; $C_{1}$ is also a factor for modification that is used to relate the expected maximum inelastic displacement to the calculated displacement for the linear elastic response; $C_{2}$ is also a modification factor corresponding to the impact of strength deterioration, cyclic stiffness degradation, and pinched hysteresis shape on the peak displacement response; $S_{\mathrm{a}}$ is the response spectra acceleration; $T_{\mathrm{e}}$ is the effective fundamental period; and $g$ is the gravity acceleration. These modification factors are calculated from Table 3-2 in ASCE 41-06. The calculation of $\mathrm{C}_{1}$ and $C_{2}$ is given in $(6 a)-(6 c)$ as follows:

$$
\begin{aligned}
C_{1} & =1+\frac{R-1}{a T_{e}^{2}} g, \\
C_{2} & =1+\frac{1}{800}\left(\frac{R-1}{T_{e}^{2}}\right)^{2}, \\
R & =\frac{S_{a}}{V_{y} / W} C_{m},
\end{aligned}
$$

where $\alpha$ is the site class factor that can be determined according to 3.3.3.3.2 of ASCE 41-06; $T_{\mathrm{e}}$ is the effective fundamental period; $V_{\mathrm{y}}$ is the strength at yield point; $\mathrm{W}$ is the total seismic weight of building; $C_{\mathrm{m}}$ is the effective mass factor obtained from Table 3-1 in ASCE 41-06; and $R$ is a ratio calculated from two parameters such as the yield strength coefficient and the demand elastic strength. The parameter $S_{\mathrm{a}}$ is expressed as

$$
\begin{aligned}
& S_{a}=S_{x s}\left[\left(\frac{5}{B_{1}}-2\right) \frac{T}{T_{s}}+0.4\right], \text { for } 0<T<T_{0}, \\
& S_{a}=\frac{S_{x s}}{B_{1}}, \quad \text { for } T_{0} \leq T \leq T_{s}, \\
& S_{a}=\frac{S_{x 1}}{\left(B_{1} T\right)}, \quad \text { for } T>T_{s},
\end{aligned}
$$

where $T_{\mathrm{s}}$ is the characteristic period of the response spectra, $S_{\mathrm{xs}}$ is a parameter that indicates design short-period spectral response acceleration at $0.2 \mathrm{sec} ; S_{\mathrm{x} 1}$ is a parameter that expresses design spectral response acceleration at $1 \mathrm{sec} ; T$ is an effective fundamental period; and $T_{0}$ is the period correlated with the variable acceleration segment of the spectra. $T_{s}$ and $T_{0}$ expressions are given as per ASCE 41-06.

$$
\begin{aligned}
& T_{s}=\frac{S_{x 1}}{S_{x s}}, \\
& T_{0}=0.2 T_{s} .
\end{aligned}
$$

The parameters $S_{\mathrm{xs}}$ and $S_{\mathrm{x} 1}$ can be calculated as per Tables 1-6, ASCE 41-06. In the present study, we considered the moderate seismicity region $\left(S_{\mathrm{xs}}=0.48\right.$ and $\left.S_{\mathrm{x} 1}=0.18\right)$. The value for $B_{1}$ can be calculated from the following equation:

$$
B_{1}=\frac{4}{[5.6-\ln (100 B)]},
$$

where $B$ is the effective viscous damping. According to clause 1.6.1.5.3 of ASCE $41-06, B$ is 0.05 .

As per clause 3.3.3.2.1 of ASCE 41-06, the general requirement is to take $150 \%$ of the target displacement $\left(\delta_{t}\right)$ which is meant to encourage engineers to investigate the building performance and behavior of the model under extreme load conditions.

\section{Model Description}

A 4-story RC symmetrical sample building model with 3 bay frames in both directions was considered as a reference structural model in this study. The story height was selected as $3 \mathrm{~m}$ for all stories in the sample model. The seismic zone was accepted as the 4 th zone for the RC building model selected as an example in this study. All structural models were produced by the authors through the SeismoStruct. Four different structural models were created, namely, Model I (full RC infilled frame in both directions), Model II (corner infill at ground story RC infilled frame in both directions), Model III (open ground story RC infilled frame in both directions), and Model IV (bare frame in both directions). The plan of the building and the 3D structural models are given in Figure 4. These different models allow the comparison of the performance of RC frame structures for different infill configurations to make realistic, practical models. 
TABLE 2: Deflection amplification factor in NEHRP [23].

\begin{tabular}{lccc}
\hline Lateral load-resisting system of RC frames & $R$ factor & $\begin{array}{c}\text { Deflection amplification } \\
\text { factor }\left(C_{d}=\mu \times R_{o}\right)\end{array}$ & $\begin{array}{c}\text { Deflection factor } \\
\left(\mathrm{DF}=C_{d} / R=\mu / R_{d}\right)\end{array}$ \\
\hline Special moment-resisting frame & 8 & 5.5 & 0.69 \\
Ordinary moment-resisting frame & 3 & 2.5 & 0.83 \\
\hline
\end{tabular}

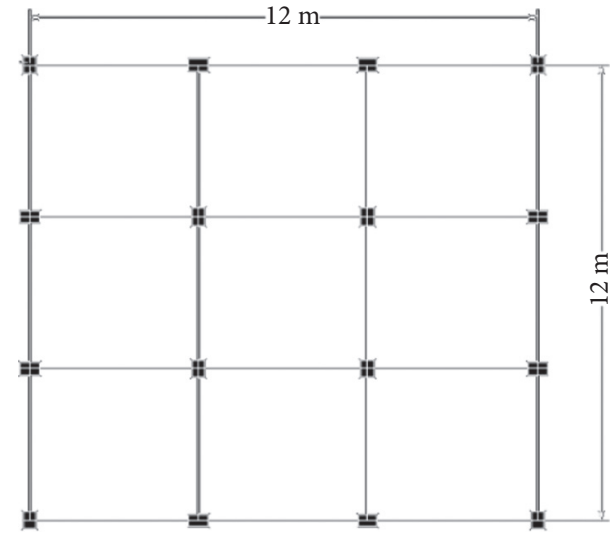

(a)

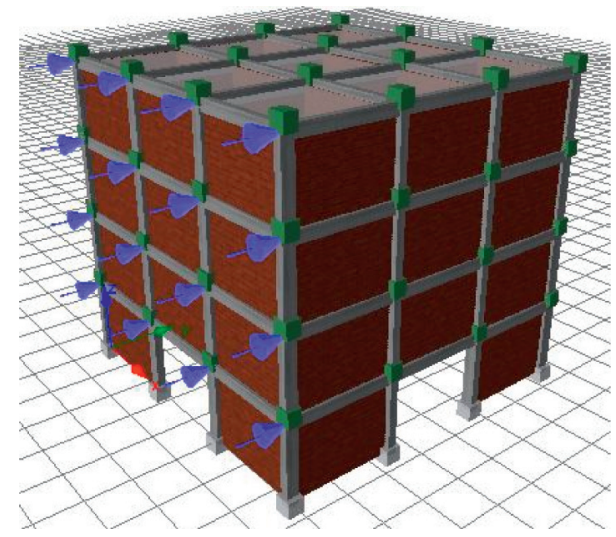

(c)

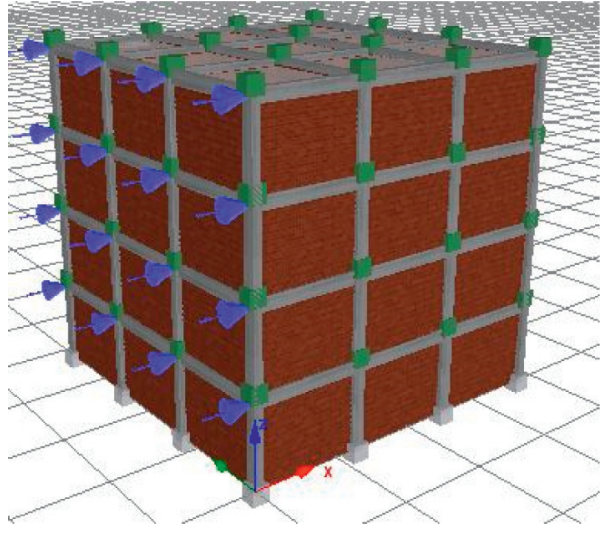

(b)

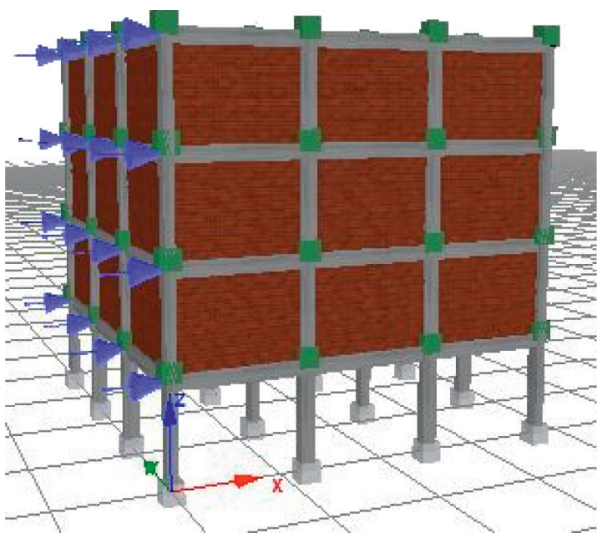

(d)

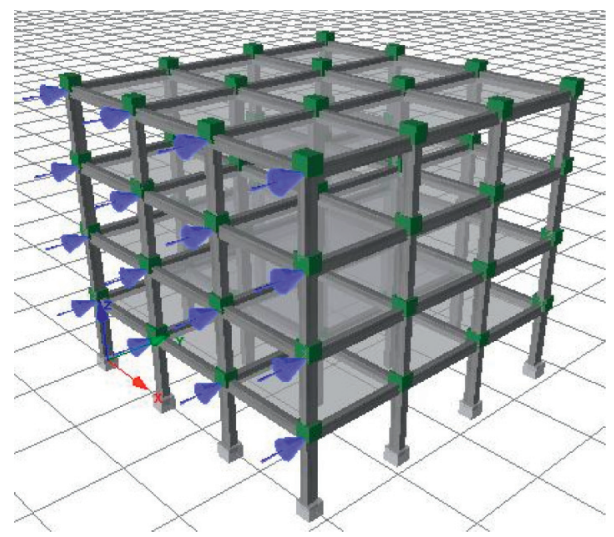

(e)

FIgure 4: Structural models in this study: (a) plan of the building; (b) Model I; (c) Model II; (d) Model III; (e) Model IV.

The detailed information about the material and sectional properties that were considered in the structural analyses is given in Table 3 .
The cross-sections of columns and beams for structural models are given in Figure 5, and detailed information about cross-sections is given in Table 4. 
TABLE 3: Material and sectional properties of models for structural analyses.

\begin{tabular}{|c|c|}
\hline Type of structure & Special moment-resisting frames \\
\hline Number of stories & 4 \\
\hline Seismic zone & IV \\
\hline Story height & $3 \mathrm{~m}$ \\
\hline Bay length & $4 \mathrm{~m}$ along the $X$ direction and $Y$ direction \\
\hline Infill wall thickness & $230 \mathrm{~mm}$ \\
\hline Compressive strengths of masonry infill $\left(f_{\mathrm{m}}\right)$ & $5 \mathrm{MPa}, 4 \mathrm{MPa}, 3 \mathrm{MPa}$ \\
\hline Young's modulus of masonry infill & $2750 \mathrm{MPa}, 2200 \mathrm{MPa}, 1650 \mathrm{MPa}$ (taken as 550 times $f_{\mathrm{m}}$, as per IS 1893 (part 1):2016) \\
\hline Type of soil & Medium stiff soil \\
\hline Column size $(\mathrm{mm})$ & $300 \times 450$ \\
\hline Beam size $(\mathrm{mm})$ & $250 \times 450$ \\
\hline Slab depth $(\mathrm{mm})$ & 150 \\
\hline Live load $\left(\mathrm{kN} / \mathrm{m}^{2}\right)$ & 3 \\
\hline Material & M 25 grade concrete and $\mathrm{Fe} 415$ reinforcement \\
\hline Damping in structure & $5 \%$ \\
\hline Importance factor & 1.5 \\
\hline
\end{tabular}

TABLE 4: Detailed information about column and beam cross-sections of the building.

\begin{tabular}{lccc}
\hline Element & Size $(\mathrm{mm})$ & Main reinforcement & Shear reinforcement \\
\hline All columns & $300 \times 450$ & $4 \phi 16$ at corners and $2 \phi 16$ on the longer sides & $\phi 8 / 100$ \\
All beams & $250 \times 400$ & $2 \phi 16$ at the top as well as at the bottom & $\phi 8 / 100$ \\
\hline
\end{tabular}

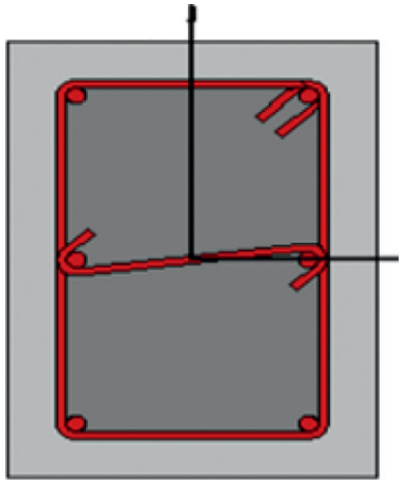

(a)

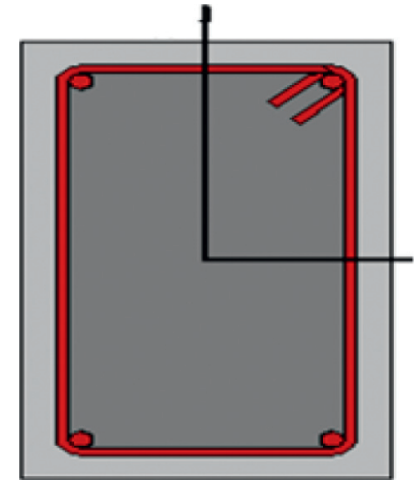

(b)

FIgURE 5: Cross-sections of columns and beams.

The infill walls are modeled as infill panel elements (inelastic) [43] in all structural models. In this study, three different values of the compressive strength of masonry infill are considered, namely, $5 \mathrm{MPa}, 4 \mathrm{MPa}$, and $3 \mathrm{MPa}$, and their impact on the $R$ values of the four different structural models is evaluated. This infill element was developed by Crisafulli [43], and it is characterized by four axial struts and two shear springs, as shown in Figure 6 [43]. The infill panel element separately accounts for shear and compressive behavior of masonry infill and adequately represents the hysteretic response; it shows a high level of accuracy. This model is also known as the "double strut nonlinear cyclic model" [43].

The presence of an opening in the infill will directly affect the structural integrity of structures, and the effect can be incorporated by minimizing the width of the diagonal strut. The stiffness reduction factor to consider the opening effect in infill in the numerical modeling is given by

$$
W_{d o}=\left(1-2.5 A_{r}\right) W_{d},
$$

where $A_{\mathrm{r}}$ is the ratio of opening area to the overall area, i.e., face area of infill. Equation (10) is valid for opening in walls greater than $5 \%$ and less than $40 \%$ [21]. In this study, opening in infill is considered as $1.2 \mathrm{~m} \times 1.2 \mathrm{~m}$ and $1 \mathrm{~m} \times 1 \mathrm{~m}$ (total opening area $=2.44 \mathrm{~m}^{2}$ ), which means that approximately $20 \%$ of the opening area is considered in the infill.

\section{Results and Discussion}

In this study, the effect of infill walls was investigated for four different structural models through static adaptive pushover analysis. The strength, ductility, and $R$ factors were obtained from adaptive pushover analysis curves. The comparison of pushover curves for all structural models is given in Figure 7. These pushover curves are represented for the $5 \mathrm{MPa}$ compressive strength of the infill wall. It is understood that 


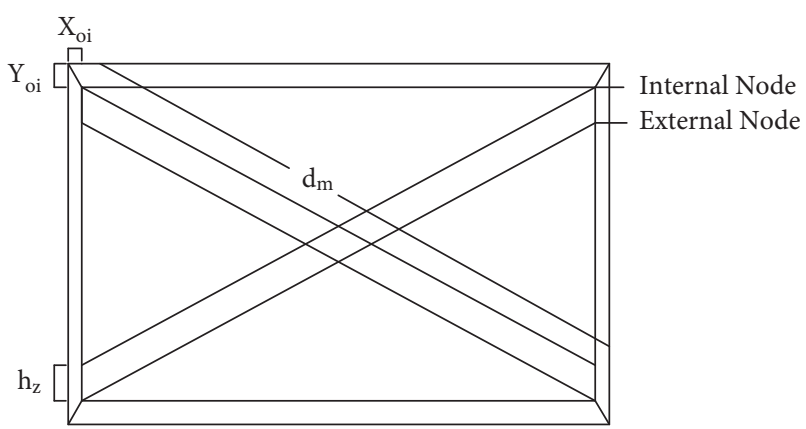

(a)

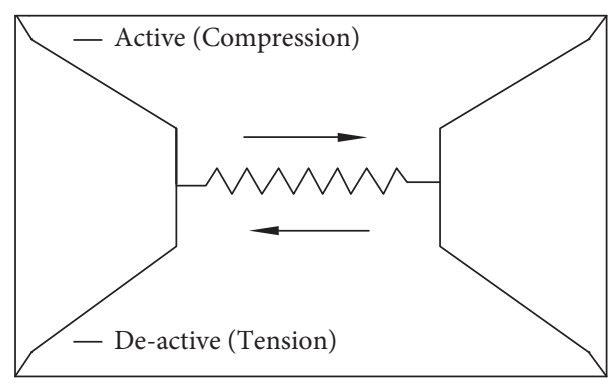

(b)

Figure 6: Inelastic infill panel element (developed by Crisafulli [43]).

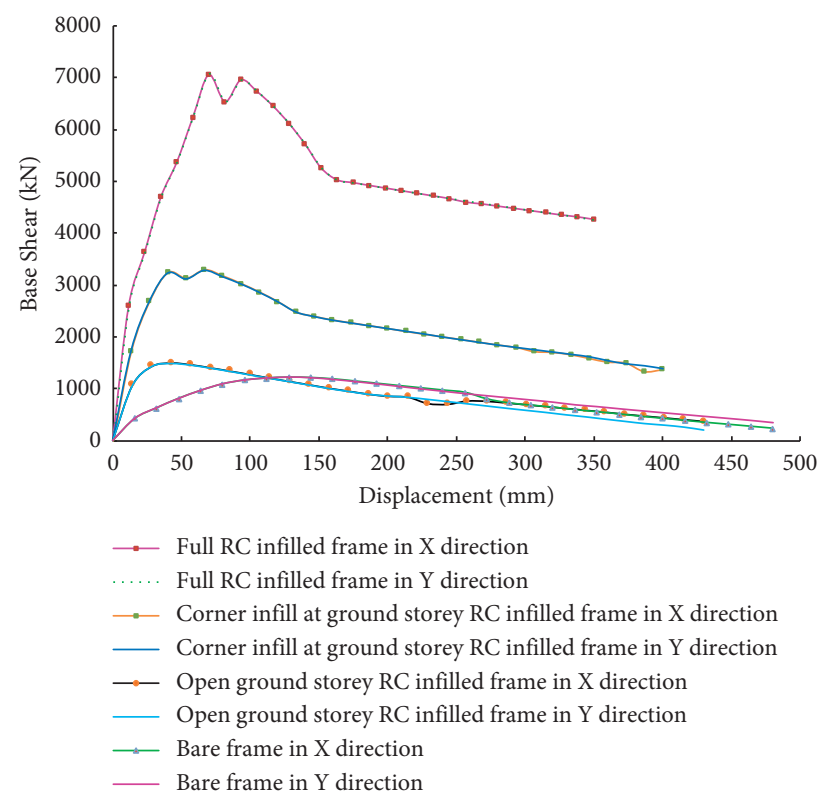

Figure 7: Comparison of pushover curves from all structural models.

RC infilled frames have maximum capacity compared to bare frames due to the effect of infill in the seismically active zone.

4.1. Base Shear. The comparison of the base shear for all structural models in both $(X$ and $Y$ ) directions for different strength of infill is given in Figure 8. The base shear was lower in bare frames than in full RC infilled frames. There is a minor change in the base shear for the different structural models in both directions due to the symmetry of the building model. Average 114.45\%, 104.21\%, and 100.29\% base shear increase were obtained in the fully infilled RC frame as compared to the corner infill at ground RC infilled frames for 5, 4, and $3 \mathrm{MPa}$ compressive strength of infill, respectively. Similarly, in the case of the corner infill at ground RC infilled frame and the open ground story (i.e., soft story RC infilled frame), there is an average base shear variation of $119.19 \%, 113.69 \%$, and $107.73 \%$ for 5,4 , and $3 \mathrm{MPa}$, respectively. Additionally, the base shear increased by an average of $23.02 \%, 22.96 \%$, and $22.73 \%$ in the open ground story (i.e., soft story) RC infilled frames as compared to the bare frames for 5,4 , and $3 \mathrm{MPa}$, respectively.

The comparison of the seismic design factors for all structural models for three different values of the compressive strength of the infill is given in Table 5 .

As per Table 5, the ductility obtained is higher for the open ground story RC infilled frame and the corner infill at ground story RC infilled frame as compared to all other frames because infill panels are absent at the ground level. The ductility increases in the open ground story RC infilled frames by an average of $19.57 \%, 13.76 \%$, and $11.31 \%$ as compared to the bare frames for compressive strength of infill 5,4 , and $3 \mathrm{MPa}$, respectively, because of the absence of the infill panel at ground level; furthermore, the initial stiffness of the open ground story $\mathrm{RC}$ infilled frame is higher than that of the bare frame. Thus, the yield point of the open ground floor RC infilled frame is less than that of the bare frame.

The ductility reduction $(R d)$ factor values are calculated on the basis of the time period and ductility. The ductility 


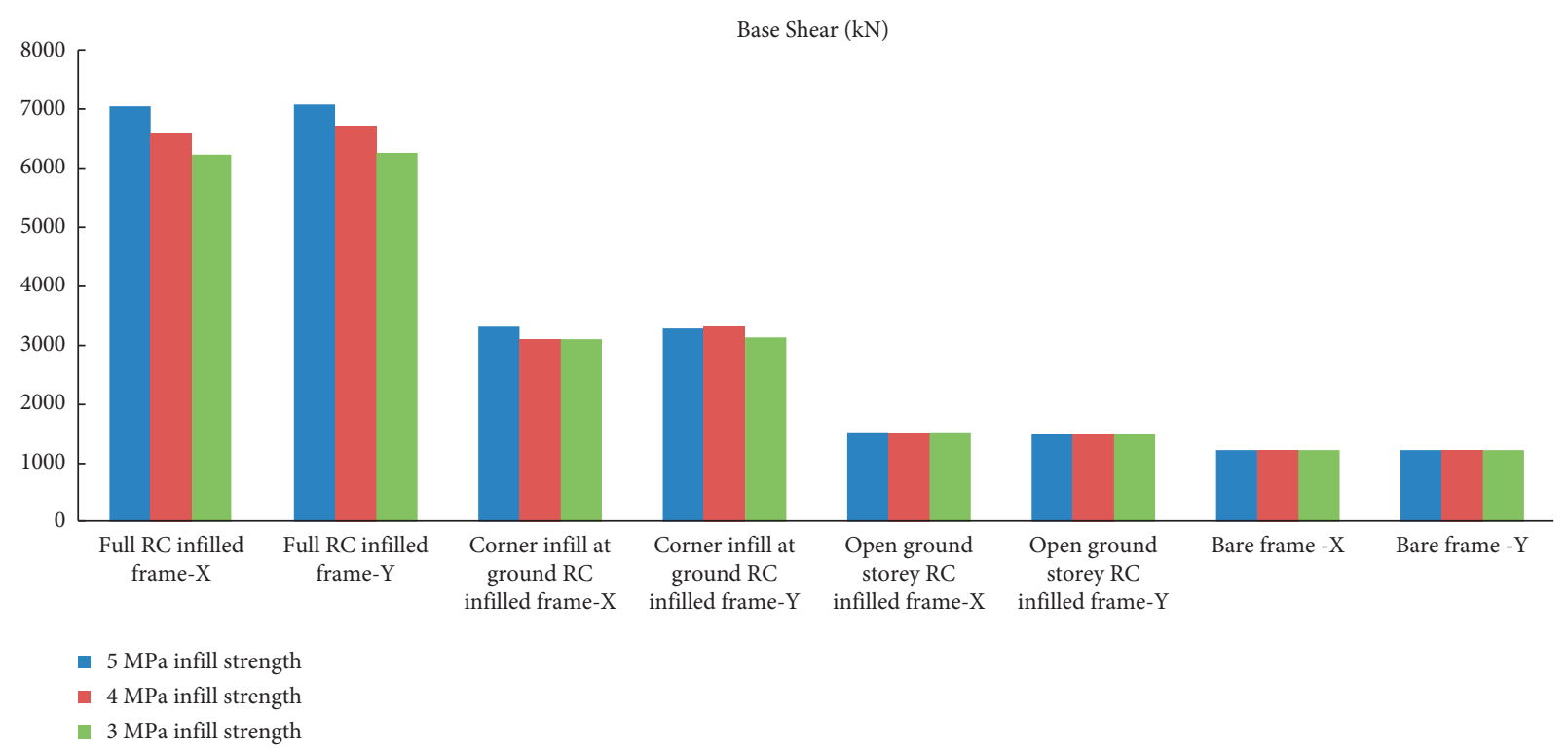

Figure 8: Comparison of base shear from all structural models.

reduction factor increases in the corner infill at ground $\mathrm{RC}$ infilled frames by an average of $2.85 \%$ as compared to the open ground story RC infilled frames for $5 \mathrm{MPa}$ compressive strength of the infill. In addition, the $R d$ increases in the open ground story RC infilled frames by an average of $3.45 \%$ and $38.93 \%$, as compared to the corner infill at ground RC infilled frames for 4 and $3 \mathrm{MPa}$ (compressive strength of infill). In the case of the bare frame, the ductility reduction factor is the same as the ductility because the bare frame behaves as a long-period structure.

The obtained overstrength factor values are higher for the full RC infilled frame as compared to all other frames because more infill panels are present in that frame. The overstrength factor increases by an average of $119.39 \%$, $113.85 \%$, and $107.39 \%$ in the corner infill at ground RC infilled frames as compared to the open ground story (i.e., the soft story) RC infilled frame for 5,4 , and $3 \mathrm{MPa}$ (compressive strength of infill), respectively, due to the greater number of infill panels at a ground story. In the case of the open ground story RC infilled frame and the bare frame, there is an average overstrength factor variation of $23.36 \%$ for 5,4 , and $3 \mathrm{MPa}$ (compressive strength of infill) due to the soft story effect, and the failure of members at a ground story is also more in the case of the open ground story RC infilled frame as compared to the bare frame.

The comparison of the $R$ factors for all structural models is given in Table 5. The obtained response reduction factor $(R)$ is higher for the full RC infilled frame than that of all other structural models. Since the $R$ factor is more dependent on the overstrength factor, the behavior of these two factors is obtained quite similarly for all frames. The $R$ factor was increased in the full RC infilled frames as compared to the corner infill at ground RC infilled frames by an average of $37.23 \%, 48.29 \%$, and $75.97 \%$ for 5, 4, and $3 \mathrm{MPa}$ (compressive strength of infill), respectively. The $R$ factor is less in the open ground story RC infilled frame and the bare frame as compared to all other frames, so these frames are highly vulnerable to the seismic action as compared to other frames. The $R$ values for the full RC infilled frames are slightly decreased as the compressive strength of the infill is reduced. In the case of the corner infill at ground RC infilled frames, the $R$ values slightly decrease more as compared to the full RC infilled frames when the compressive strength of infill reduces. The deflection factors for all structural models are almost more than the value 1.

4.2. Time Period. Figure 9 shows the time period of different structural models. The time period of the bare frame is more as compared to all others due to the absence of infill in the structure. The full RC infilled frame shows the minimum time period as compared to other models. Moreover, as per the compressive strength of infill, the $3 \mathrm{MPa}$ RC infilled frame has more time period than the other RC infilled frames (i.e., the $4 \mathrm{MPa}$ and $5 \mathrm{MPa} \mathrm{RC}$ infilled frames) due to the smaller compressive strength of infill present in these structures.

4.3. Performance Point. Table 6 shows the average performance point (in $X$ and $Y$ direction) of all four RC models, along with the different compressive strength of infill (i.e., $5 \mathrm{MPa}, 4 \mathrm{MPa}$, and $3 \mathrm{MPa}$ ). Full $\mathrm{RC}$ infilled frame and corner infill at ground story RC infilled frame are showing the minimum performance point as compared to the other two models due to the presence of maximum infill in the RC frame. On the other hand, the bare frame and open ground story RC infilled frame are showing the maximum performance point as compared to others due to less infill present in these RC frames. Furthermore, as the compressive strength of the infill increases, the performance point of the structure decreases because the infill plays an important role in enhancing the stiffness and strength of the structure. In general, the performance point of the structure should be minimal to get a good seismic response. 


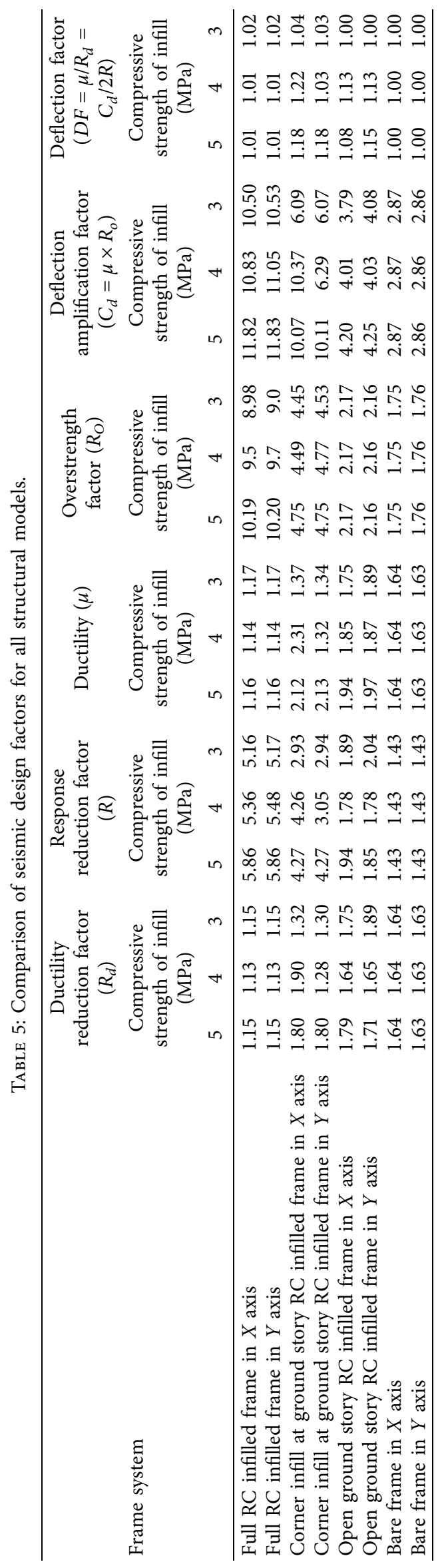




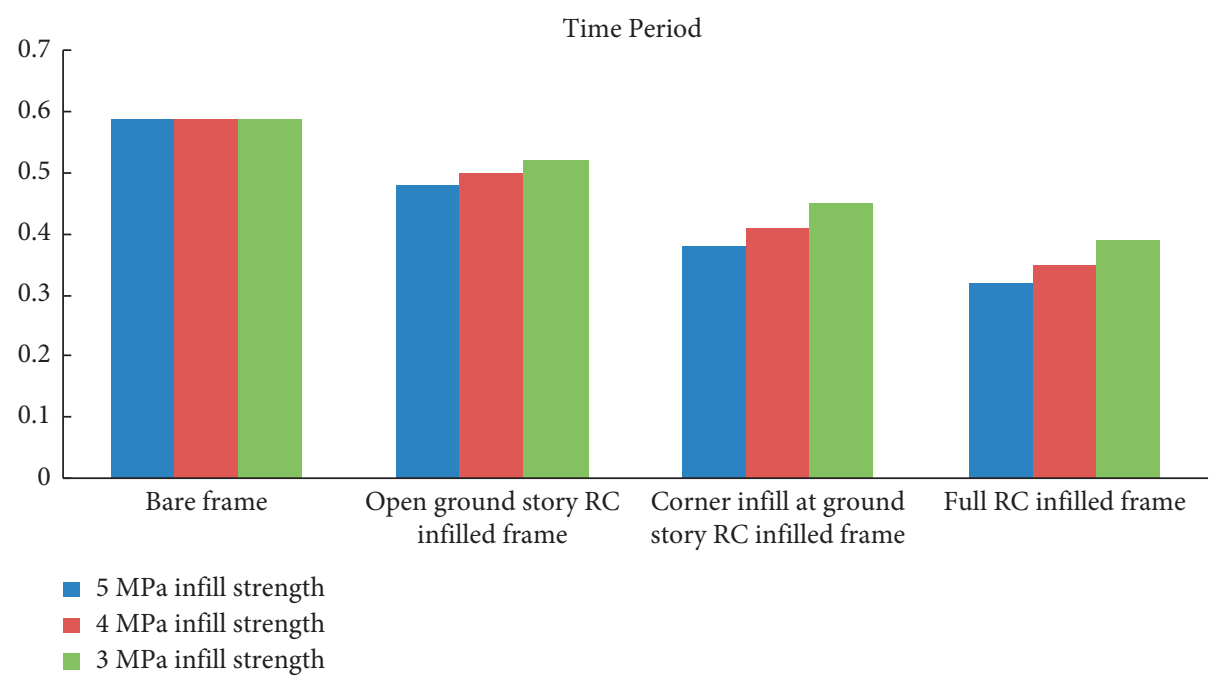

Figure 9: Comparison of the time period from all structural models.

TABle 6: Comparison of the performance point for all structural models.

\begin{tabular}{|c|c|c|c|}
\hline \multirow{3}{*}{ Frame system } & \multicolumn{3}{|c|}{ Average performance point (mm) } \\
\hline & \multicolumn{3}{|c|}{ Compressive strength of infill (MPa) } \\
\hline & 5 & 4 & 3 \\
\hline Bare frame & 76.83 & 76.83 & 76.83 \\
\hline Open ground story RC infilled frame & 76.33 & 77.1 & 77.98 \\
\hline Corner infill at ground story RC infilled frame & 39.3 & 41.52 & 42.07 \\
\hline Full RC infilled frame & 8.31 & 15.79 & 22.78 \\
\hline
\end{tabular}

4.4. $R$ Factor versus Performance Point. Figure 10 shows the $\mathrm{R}$ factor versus performance point relationship for all structural models. As per Figure 10, as the compressive strength of the infill decreases, the performance point of structure increases, while the response reduction factor decreases. In the case of the full RC infilled frame, the behavior of points is almost linear as the compressive strength decreases due to regularity in the structure; on the other hand, in the case of the corner infill at ground RC infilled frame, there is a sudden drop-down in the behavior of points as the compressive strength decreases due to some irregular stiffness present in the structure. In addition, in the case of the open ground story RC infilled frame, the points are very close to each other, which means there is no significant effect on the structure as the compressive strength of infill decreases because of the drastic change in the stiffness of the structure. The bare frame shows a higher performance point as compared to other models because the infill is absent in this frame. Generally, the response reduction factor of the structure should be high to obtain good stiffness, strength, and ductility in the structure, so based on the observation, as the performance point of the structure decreases, the response reduction factor increases.

4.5. Damage Pattern. In this study, the damage patterns of all structural models were also compared. For this purpose, the performance criteria based on the material strain are

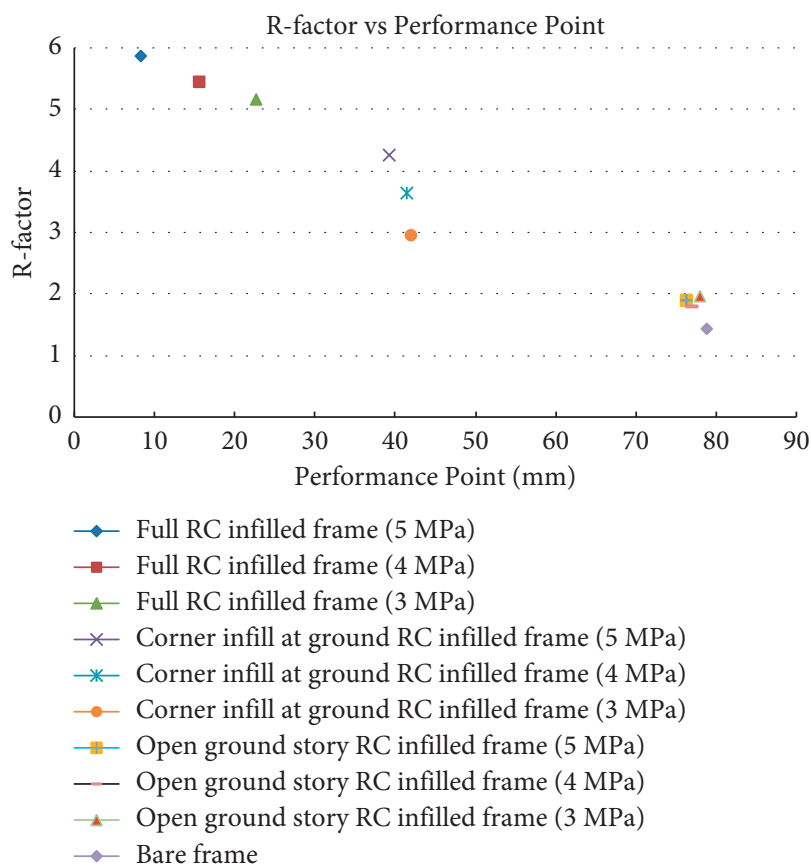

Figure 10: $R$ factor versus performance point graph for all structural models.

used herein as follows: (i) unconfined concrete's crushing strain limit: 0.0035 , (ii) confined concrete's crushing strain limit: 0.008, (iii) yield strain limit for structural steel: 0.0025 , 


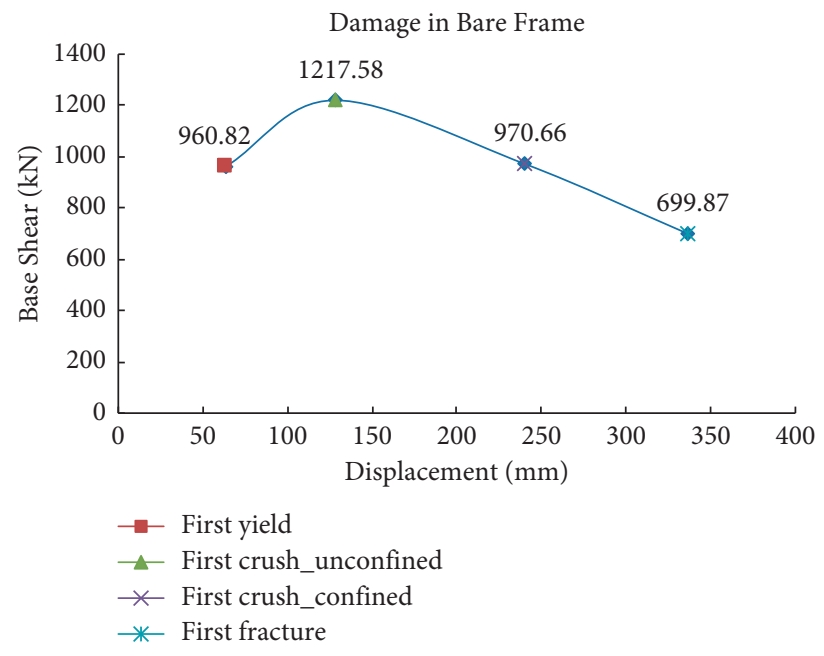

Figure 11: Damage patterns for the bare frame.

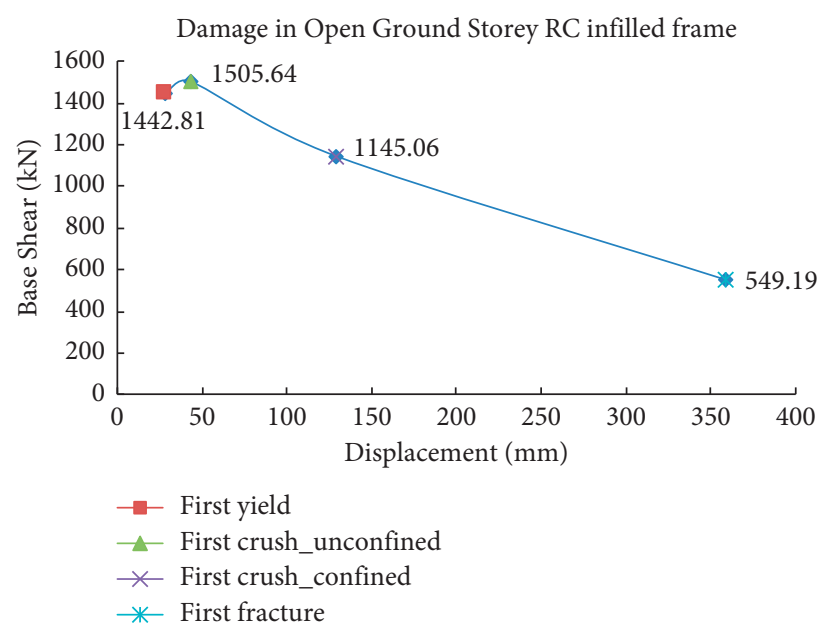

(a)

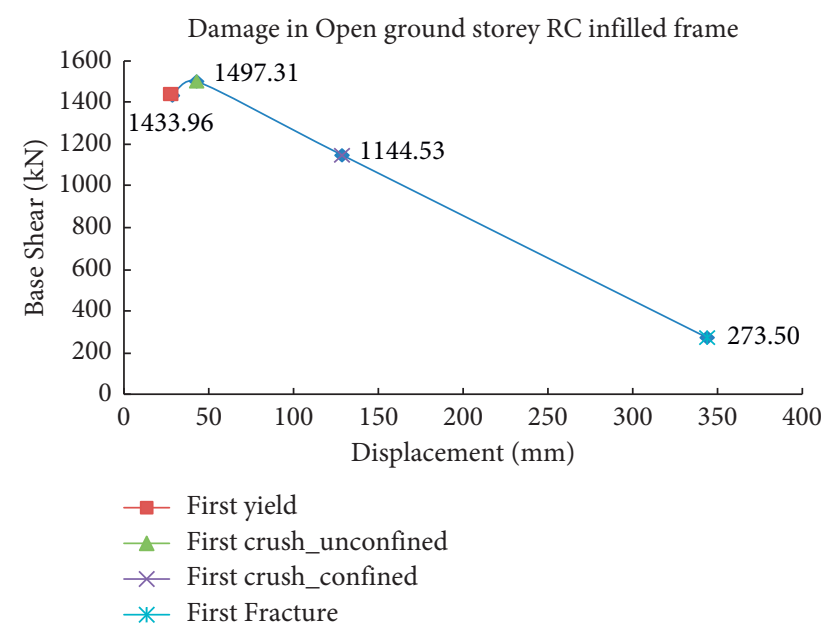

(b)

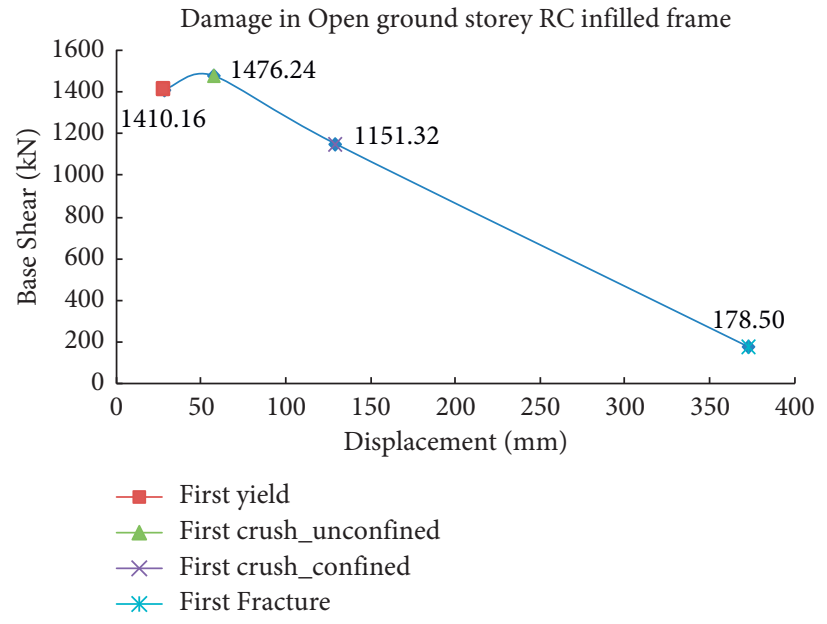

(c)

FIGURE 12: Damage in open ground story RC infilled frame for different values of the compressive strength of infill: (a) $5 \mathrm{MPa}$; (b) $4 \mathrm{MPa}$; (c) $3 \mathrm{MPa}$. 


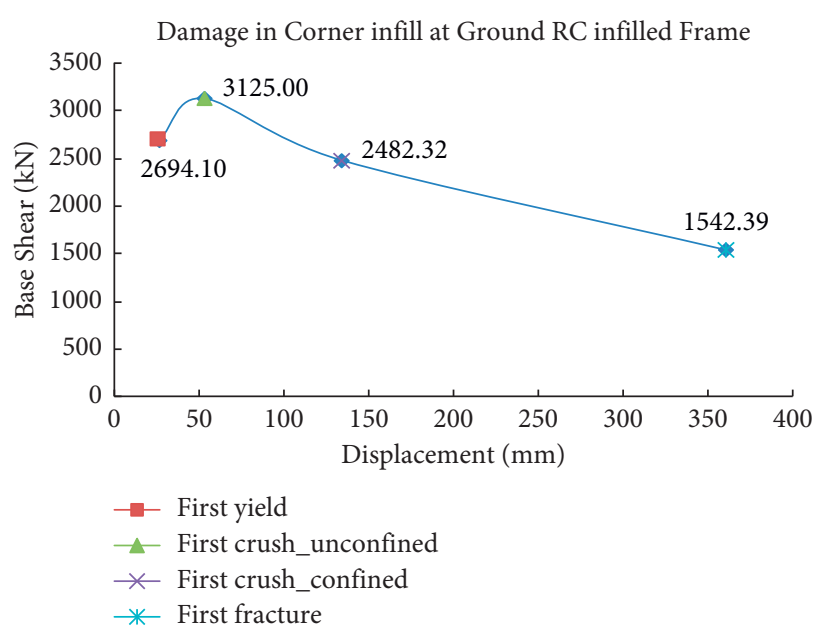

(a)

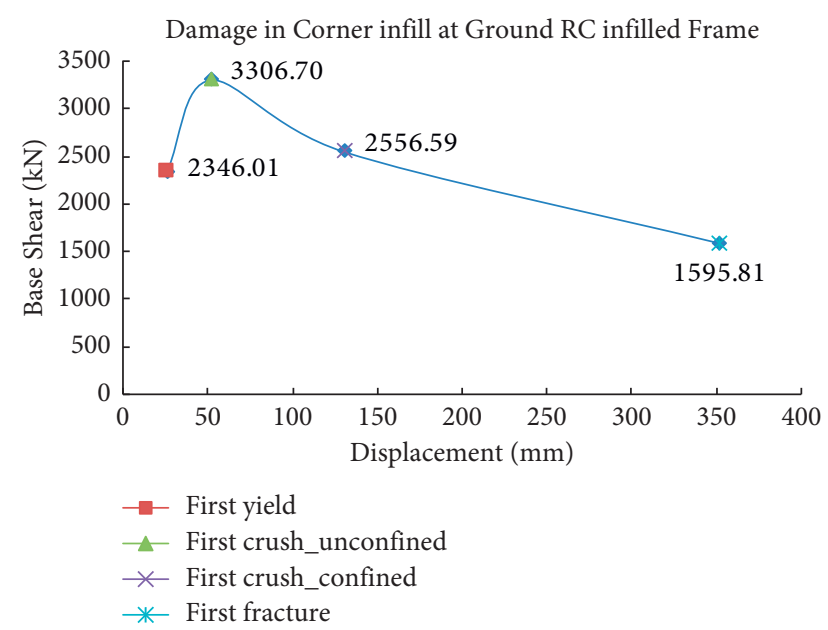

(b)

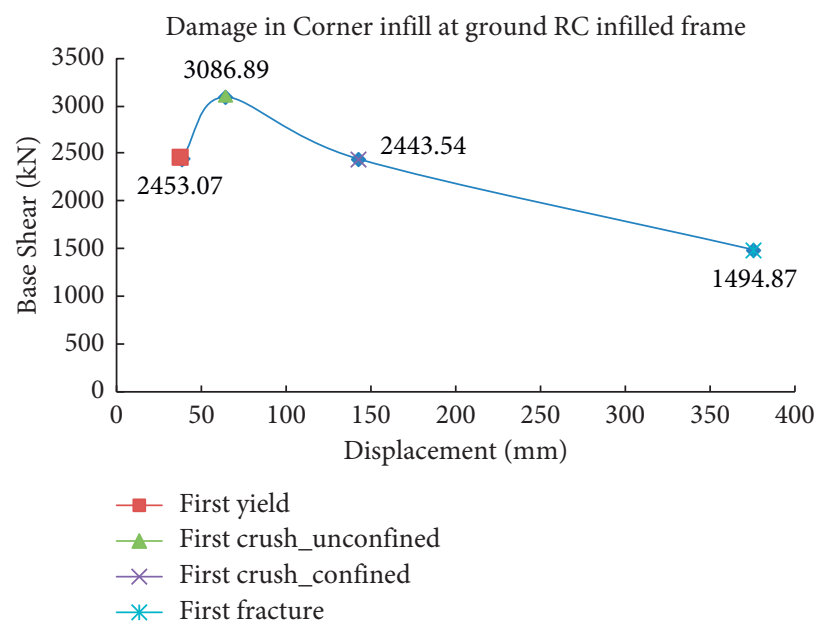

(c)

FIGURE 13: Damage pattern of the corner infill at ground RC infilled frame for different values of the compressive strength of infill: (a) $5 \mathrm{MPa}$; (b) $4 \mathrm{MPa}$; (c) $3 \mathrm{MPa}$.

and (iv) fracture strain limit for steel: 0.06 [44-47]. The values of the damage pattern for Model IV (bare frame) are given in Figure 11.

The first yield of the reinforcement has occurred at a base shear of $960.82 \mathrm{kN}$ and displacement of $64 \mathrm{~mm}$. This yield displacement is more as compared to all other frames because of the low stiffness in the bare frame. The "first crushed unconfined concrete" (i.e., spalling of concrete cover) occurred at base shear of $1217.58 \mathrm{kN}$ and displacement of $128 \mathrm{~mm}$; the "first crushed confined concrete" (i.e., of the core portion of concrete) occurred at $970.66 \mathrm{kN}$ base shear force and $240 \mathrm{~mm}$ displacement; and the first fracture occurred at $699.82 \mathrm{kN}$ base shear and $336 \mathrm{~mm}$ displacement; i.e., the bare frame goes up to its ultimate stage.

The damage patterns for the open ground story RC infilled frame for different compressive strengths of the infill are given in Figure 12. The first yield point for reinforcement occurred at base shear of $1442.81 \mathrm{kN}$ and displacement of $28.67 \mathrm{~mm}$ for infill compressive strength of $5 \mathrm{MPa}$. This yield displacement is less as compared to the bare frame because of the high stiffness in the open ground story frame as compared to the bare frame. The first crushed unconfined concrete (i.e., spalling of concrete cover) occurred at base shear of $1505.64 \mathrm{kN}$ and displacement of $43 \mathrm{~mm}$; the first crushed confined concrete (i.e., the core portion of concrete) occurred at base shear of $1145.06 \mathrm{kN}$ and displacement of $129 \mathrm{~mm}$; and the first fracture occurred at base shear of $549.19 \mathrm{kN}$ when the displacement reached $358.33 \mathrm{~mm}$. The damage for the RC frames starts early for the case of $3 \mathrm{MPa}$ compressive strength of infill as compared to other values of compressive strength of infill.

The damage patterns for the corner infill at the ground $\mathrm{RC}$ infilled frame of different values of compressive strength of infill are given in Figure 13. The first yield of reinforcement occurred at a base shear of $2694.10 \mathrm{kN}$ when the displacement had reached $26.67 \mathrm{~mm}$. This yield displacement is less as compared to all other frames because of the high stiffness, and so it gives more ductility. The first crushed unconfined concrete (i.e., spalling of concrete cover) 


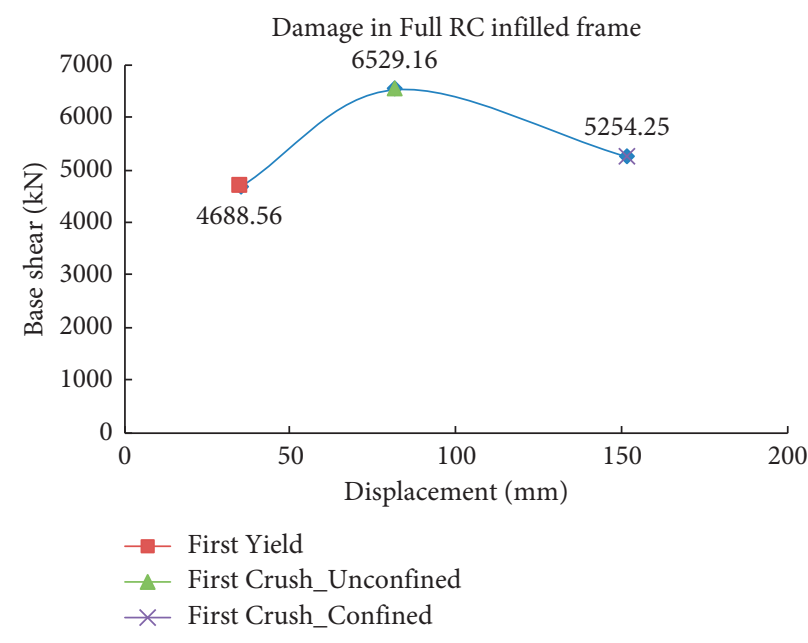

(a)

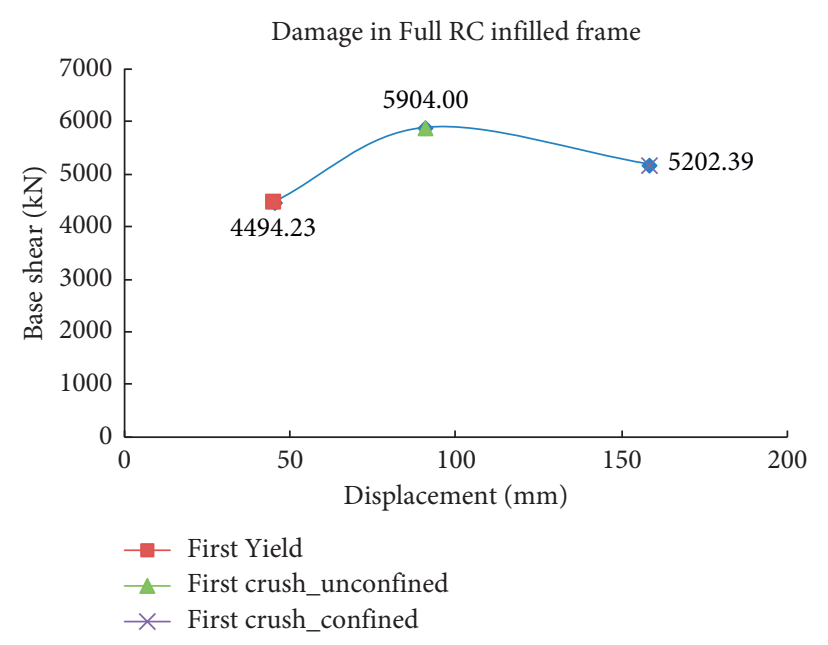

(b)

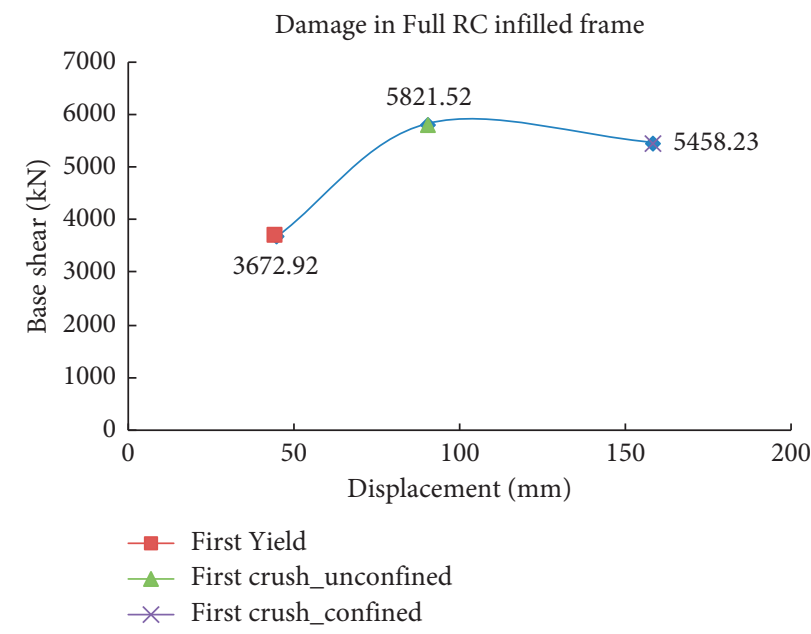

(c)

Figure 14: Damage pattern of the full RC infilled frame for different values of the compressive strength of infill: (a) $5 \mathrm{MPa}$; (b) $4 \mathrm{MPa}$; (c) $3 \mathrm{MPa}$.

occurred at a base shear of $3125 \mathrm{kN}$ and the displacement had reached $53.33 \mathrm{~mm}$; the first crushed confined concrete (i.e., the core portion of concrete) occurred at a base shear of $2482.32 \mathrm{kN}$ when the displacement had reached $133.33 \mathrm{~mm}$; finally, the first fracture occurred at a base shear of $1542.39 \mathrm{kN}$ when the displacement had reached $360 \mathrm{~mm}$.

The damage patterns of the full RC infilled frame for the three different values $(5 \mathrm{MPa}, 4 \mathrm{MPa}$, and $3 \mathrm{MPa})$ of the compressive strength of infill are given in Figure 14.

In the case of infill compressive strength of $5 \mathrm{MPa}$ (Figure 14(a)), the first reinforcement yield occurred at $35 \mathrm{~mm}$ displacement and $4688.56 \mathrm{kN}$ base shear force. The full RC infilled frame sustains more loads as compared to all other frames. The first crushed unconfined concrete occurred when the displacement was $81.67 \mathrm{~mm}$, and the base shear was $6529.16 \mathrm{kN}$. The first crushed confined concrete occurred at $5254.25 \mathrm{kN}$ base shear and $151.67 \mathrm{~mm}$ displacement.

As observed in Figure 14, the damage starts earlier for the case of $3 \mathrm{MPa}$ infill compressive strength as compared to the values $4 \mathrm{MPa}$ and $5 \mathrm{MPa}$ of the compressive strength of the infill.

\section{Conclusions}

Masonry infill has a positive contribution to the earthquake behavior of RC buildings. As per the presented computational results, the conclusions from this research are as follows:

(1) The incorporation of infill panels in frame structures expressively enhances the stiffness of structures, and it results in the reduction in fundamental periods.

(2) As the compressive strength of infill reduces, the performance point of structures increases, while the response reduction factor decreases.

(3) The ductility and ductility reduction factors are higher in the open ground story RC infilled frames as compared to all other frames because the yield displacement point is minimal compared to all other frames due to high stiffness. However, as the compressive strength of masonry infill reduces, the ductility is also slightly reduced in the open ground story RC infilled frames because the change in 
stiffness between ground and other stories is minimal.

(4) The overstrength factor is significantly affected by the presence of infill in the frame. Furthermore, as a result, the response reduction factor of the full $\mathrm{RC}$ infilled frame is higher than that of the other frames in seismically active zones.

(5) The computed values of the $R$ factor for bare frames obtained by the adaptive pushover analysis of buildings are less than the value suggested in the BIS code (IS 1893 (Part 1): 2016). It is worth noting that, after incorporation of infill in frames for different infill configurations along with openings to make a realistic structure, the computed values of the $R$ factor for the open ground story (i.e., soft story RC infilled frame) and the bare frame are less than the value recommended by the IS 1893 (Part 1):2016, because the BIS code is silent about different issues like geometrical configurations, irregularities, and incorporation of infill.

(6) As per the damage pattern of this study, the open ground story RC infilled frame and the bare frame are unsafe; therefore, the $R$ values of these frames are less than the recommended value by the BIS code. Additionally, the corner infill at the ground story RC infilled frame is also in an unsafe condition when the compressive strength of the masonry infill is $3 \mathrm{MPa}$.

(7) According to the present study, the $R$ factor is overestimated in the BIS code for the bare frame (i.e., moment-resisting frame), which, in turn, leads to a significantly lower estimate of the design base shear resulting in a more seismically vulnerable structure.

(8) The deflection factor can be higher than 1.0 for a ductile frame system with infill. The deflection factor recommended by the NEHRP provisions for special moment-resisting RC frames is low and therefore needs to be modified. Additionally, the BIS code (IS 1893 (Part 1): 2016) should incorporate the value of the deflection factor for different structural systems.

\section{Data Availability}

Data used to support the findings of this study are included within the article.

\section{Conflicts of Interest}

The authors declare that there are no conflicts of interest.

\section{References}

[1] S. Pul and M. E. Arslan, "Cyclic behaviors of different type of hollow brick infill walls: a hinged rigid frame approach," Construction and Building Materials, vol. 211, pp. 899-908, 2019.

[2] S. W. Choi, S. W. Park, and H. S. Park, "Multi-objective design model for retrofit of reinforced concrete frames with infilled walls using FRP bracings," Construction and Building Materials, vol. 140, pp. 454-467, 2017.
[3] O. Öztürkoğlu, U. Taner, and Y. Yesilce, "Investigation of infill wall-frame interaction in reinforced concrete structures," Dokuz Eylul University Faculty of Engineering J. Sci. Eng., vol. 17, no. 51, pp. 109-121, 2015.

[4] O. Akyürek, H. Tekeli, and F. Demir, "Effect of infill wall placement in plan on building performance," Int. J. Eng. Res. Development, vol. 10, no. 1, pp. 42-55, 2018.

[5] G. V. Mulgund and A. B. Kulkarni, "Seismic assessment of RC frame buildings with brick masonry infills," Int. J. Advanced Eng. Sci. Techn.vol. 2, no. 2, pp. 140-147, 2011.

[6] A. Tabrizikahou, M. Kuczma, P. Nowotarski, M. Kwiatek, and A. Javanmardi, "Sustainability of civil structures through the application of smart materials: a review," Materials, vol. 14, no. 17, Article ID 4824, 2021.

[7] P. Ricci, M. Di Domenico, and G. M. Verderame, "Experimental investigation of the influence of slenderness ratio and of the in-plane/out-of-plane interaction on the out-of-plane strength of URM infill walls," Construction and Building Materials, vol. 191, pp. 507-522, 2018.

[8] A. Furtado, H. Rodrigues, A. Arêde, and H. Varum, "Out-ofplane behavior of masonry infilled RC frames based on the experimental tests available: a systematic review," Construction and Building Materials, vol. 168, pp. 831-848, 2018.

[9] M. Dolsek and P. Fajfar, "The effect of masonry infills on the seismic response of a four storey reinforced concrete frame- a deterministic assessment," Engineering Structures, vol. 30, pp. 1991-2001, 2008.

[10] H. Dilmac, H. Ulutas, H. Tekeli, and F. Demir, "The investigation of seismic performance of existing RC buildings with and without infill walls," Computers and Concrete, vol. 22, no. 5, pp. 439-447, 2018.

[11] A. Tabrizikahou, M. Hadzima-Nyarko, M. Kuczma, and S. Lozančić, "Application of shape memory alloys in retrofitting of masonry and heritage structures based on their vulnerability revealed in the Bam 2003 earthquake," Materials, vol. 14, no. 16, Article ID 4480, 2021.

[12] M. H. Arslan, "An evaluation of effective design parameters on earthquake performance of RC buildings using neural networks," Engineering Structures, vol. 32, no. 7, pp. 1888-1898, 2010.

[13] B. Li, Z. Wang, K. M. Mosalam, and H. Xie, "Wenchuan earthquake field reconnaissance on reinforced concrete framed buildings with and without masonry infill walls," in The 14th World Conference on Earthquake Engineering, Beijing, China, 2008.

[14] Y. P. Yuen and J. S. Kuang, "Nonlinear seismic responses and lateral force transfer mechanisms of RC frames with different infill configurations," Engineering Structures, vol. 91, pp. 125-140, 2015.

[15] A. Madan, A. M. Reinhorn, J. B. Mander, and R. E. Valles, "Modeling of masonry infill panels for structural analysis," Journal of Structural Engineering, vol. 123, no. 10, pp. 1295-1302, 1997.

[16] M. M. Köse, "Parameters affecting the fundamental period of RC buildings with infill walls," Engineering Structures, vol. 31, no. 1, pp. 93-102, 2009.

[17] U. Akpinar and B. Binici, "The effect of infill wall collapse on the deformation estimations of reinforced concrete frames," J. Civ. Eng. Sci.vol. 2, no. 3, pp. 171-177, 2013.

[18] P. Rathod and S. S. Dyavanal, "Seismic evaluation of multistory RC building with openings in unreinforced masonry infill walls with user defined hinges," in Proceedings of the IRF International Conference, pp. 115-120, Bengaluru, India, July 2014. 
[19] T. M. Alguhane, H. K. Ayman, M. N. Fayed, and M. I. Ayman, "Seismic assessment of old existing RC buildings with masonry infill in Madinah as per ASCE," Int. J. Civ. Environ. Struct. Constr. Archi. Eng.vol. 9, no. 1, pp. 52-63, 2015, https:// doi.org/10.5281/zenodo.1099078.

[20] “ASCE/SEI 41-06," Seismic Rehabilitation of Existing Buildings, American Society of Civil Engineers, Reston, Virginia, 2007.

[21] S. S. Goud and R. Pradeepkumar, "Rationalizing response reduction factor (R) for better performance of reinforced concrete framed buildings," in National Conference on Recent Research Advances in Civil Engineering, pp. 1-6, Osmania University, Hyderabad, India, November 2014.

[22] C. M. Uang, "Establishing R (or rw) and Cd factors for building seismic provisions," Journal of Structural Engineering, vol. 117, no. 1, pp. 19-28, 1991, ASCE)0733-9445.

[23] NEHRP, Recommended Provisions for Seismic Regulations for New Buildings, Building Seismic Safety Council, Washington, D.C, 1994.

[24] M. Shendkar and R. Pradeepkumar, "Response reduction factor of RC framed structures with semi-interlocked masonry and unreinforced masonry infill," Indian Concrete Institute (ICI) Journal, vol. 1, pp. 24-28, 2018.

[25] J. M. Estêvão and C. S. Oliveira, "A new analysis method for structural failure evaluation," Engineering Failure Analysis, vol. 56, pp. 573-584, 2015.

[26] E. Işık, M. Özdemir, and İ. B. Karaşin, "Performance analysis of steel structures with A3 irregularities," Int. J. Steel Struct.vol. 18, no. 3, pp. 1083-1094, 2018.

[27] E. Kalkan and S. K. Kunnath, "Adaptive modal combination procedure for nonlinear static analysis of building structures," Journal of Structural Engineering, vol. 132, no. 11, pp. 1721-1731, 2006.

[28] B. Gupta and S. K. Kunnath, "Adaptive spectra-based pushover procedure for seismic evaluation of structures," Earthquake Spectra, vol. 16, no. 2, pp. 367-391, 2000.

[29] S. Antoniou and R. Pinho, "Advantages and limitations of adaptive and non-adaptive force-based pushover procedures," Journal of Earthquake Engineering, vol. 8, no. 4, pp. 497-522, 2004.

[30] V. K. Papanikolaou and A. S. Elnashai, "Evaluation of conventional and adaptive pushover analysis I: Methodology," Journal of Earthquake Engineering, vol. 9, no. 6, pp. 923-941, 2005.

[31] S. Antoniou and R. Pinho, "Development and verification of a displacement-based adaptive pushover procedure," Journal of Earthquake Engineering, vol. 8, no. 5, pp. 643-661, 2004.

[32] SeismoStruct, "A Computer Program for Static and Dynamic Nonlinear Analysis of Framed Structures," Seismosoft Ltd., Pavia, Italy, 2020, http://www.seismosoft.com.

[33] R. Pinho and S. Antoniou, "A displacement-based adaptive pushover algorithm for assessment of vertically irregular frames," in Proceedings of the Fourth European Workshop on the Seismic Behaviour of Irregular and Complex, Structures, Thessaloniki, Greece, January 2005.

[34] Pacific Earthquake Engineering Research Center (PEER), PEER Strong Ground Motion Databases, Pacific Earthquake Engineering Research Center, University of California, Berkeley, CA, USA, 2020, https://peer.berkeley.edu/peerstrong-ground-motion-databases available online: accessed on 10-10-2020).

[35] E. Işık, A. Büyüksaraç, Y. L. Ekinci, M. C. Aydın, and E. Harirchian, "The effect of site-specific design spectrum on earthquake-building parameters: a case study from the
Marmara Region (NW Turkey)," Applied Sciences, vol. 10, no. 20 , p. $7247,2020$.

[36] H. Chaulagain, H. Rodrigues, E. Spacone, R. Guragain, R. Mallik, and H. Varum, "Response reduction factor of irregular RC buildings in Kathmandu valley," Earthquake Engineering and Engineering Vibration, vol. 13, no. 3, pp. 455-470, 2014.

[37] A. Mondal, S. Ghosh, and G. R. Reddy, "Performance-based evaluation of the response reduction factor for ductile RC frames," Engineering Structures, vol. 56, pp. 1808-1819, 2013.

[38] ATC 19, Seismic Response Modification Factors, Applied Technical Council (ATC), Redwood City, CA, USA, 1995.

[39] IS 1893, Criteria For Earthquake Resistant Design Of Structures-Part1 General Provisions And Buildings (Sixth Revision), Bureau of Indian Standards (BIS), New Delhi, India, 2016.

[40] R. Park, "Ductility evaluation from laboratory and analytical testing,"vol. 8, pp. 605-616, in Proceedings of the 9th World Conference on Earthquake Engineering, vol. 8, pp. 605-616, University of Tokyo, Japan, August 1988.

[41] N. M. Newmark and W. J. Hall, Earthquake Spectra and Design, Earthquake Engineering Research Institute, Berkeley, California, 1982.

[42] R. K. Mohammadi, "Approximate evaluation of deflection amplification factor," Journal of Structural Engineering, vol. 128, pp. 179-187, 2002.

[43] F. J. Crisafulli, Seismic Behavior of Reinforced concrete Structures with Masonry Infills, Ph.D. Thesis, University of Canterbury, New Zealand, 1997.

[44] P. T. Aswin, Seismic Evaluation of 4-story Reinforced concrete Structure by Non-linear Static Pushover analysis, Bachelor of Technology Thesis, National Institute of Technology, Rourkela, 2013.

[45] M. R. Shendkar, D.-P. N. Kontoni, S. Mandal, P. R. Maiti, and D. Gautam, "Effect of lintel beam on seismic response of reinforced concrete buildings with semi-interlocked and unreinforced brick masonry infills," Infrastructures, vol. 6, no. 1, pp. 1-18, Article ID 6, 2021.

[46] M. R. Shendkar, D.-P. N. Kontoni, S. Mandal, P. R. Maiti, and O. Tavasoli, "Seismic evaluation and retrofit of reinforced concrete buildings with masonry infills based on material strain limit approach," Shock and Vibration, vol. 2021, pp. 1-15, Article ID 5536409, 2021.

[47] M. R. Shendkar, R. Pradeep Kumar, S. Mandal, P. R. Maiti, and D.-P. N. Kontoni, "Seismic risk assessment of reinforced concrete buildings in Koyna-Warna region through EDRI method," Innovative Infrastructure Solutions, vol. 6, no. 3, pp. 1-25, Article ID 141, 2021. 